\title{
Pertumbuhan dan Pembungaan Tanaman Koro Pedang (Canavalia ensiformis) pada Kondisi Ternaungi dan Kombinasi Pemupukan Berbeda
}

\section{Growth and Flowering of Jack Bean Plant (Canavalia ensiformis) in Condition of Shade and Different Combinations of Fertilizer}

\section{Mutthiah Putri Saragih, Tatiek Kartika Suharsi dan Abdul Qadir}

\author{
Departemen Agronomi dan Hortikultura, Fakultas Pertanian, Institut Pertanian Bogor \\ (Bogor Agricultural University), Jalan Meranti, Kampus IPB Dramaga, Bogor 16680, Indonesia \\ Telp. \& Faks. 0251-8629353 e-mail: agronipb@indo.net.id \\ *Penulis untuk korespondensi : tsuharsi@yahoo.co.id
}

Disetujui 20 Agustus 2018 / Published online 3 September 2018

\begin{abstract}
Highly of needed society about soybean, whereas productivity of soybean low in Indonesia, should import soybean from other country in amount much. Some comodity which potential as subtitute soybean between koro pedang. soybean had high protein content and growth to be able on shading condition as positive side from koro pedang. Therefore the research about percent light into shading to find tolerance of koro pedang plant with combination the best fertilizing. The research aimed to study was characteristic of flowering of Jack bean in shading level, to obtain information best fertilitizion, and to study was shading level and fertilizing to flowering of Jack bean.The research was conducted Purwasari Field, Dramaga, Bogor Mey until November 2016. The research design used was Split Plot with three replication. The first factor as main plot where that consisted of 3 shading level, i.e: unshade, 10\% shading, and $20 \%$ shading. The second factor as a sub plot where dosage of fertilizer that consisted of 3 level: Urea $50 \mathrm{~kg} \mathrm{ha} \mathrm{h}^{-1}+S P-36$ $100 \mathrm{~kg} \mathrm{ha}^{-1}+\mathrm{KCl} 75 \mathrm{~kg} \mathrm{ha}^{-1}$, organic poultary breeding fertilize, dan Urea $25 \mathrm{~kg} \mathrm{ha}{ }^{-1}+S P-3650 \mathrm{~kg} \mathrm{ha}+\mathrm{KCl}$ $37.5 \mathrm{~kg} \mathrm{ha} a^{-1}+$ organic fertilizer. The result showed that shading $10 \%$ influence plant high is $18,35 \mathrm{~cm}$ and $94,80 \mathrm{~cm}$, total leaf is 11,75 leaf, total branch is 2,47 branch, total infloresenece is 21,54 infloresenece and total flowers bud is 1 flowers bud. The best fertilization treatment is $25 \mathrm{~kg} \mathrm{ha}^{-1}$ urea $+50 \mathrm{~kg} \mathrm{ha} \mathrm{a}^{-1} \mathrm{SP}-36+$ $37,5 \mathrm{~kg} \mathrm{ha}^{-1} \mathrm{KCl}+$ organic fertilization.
\end{abstract}

Keywords : characteristic, infloresenece, $\mathrm{KCl}$, SP-36, urea

\begin{abstract}
ABSTRAK
Kebutuhan masyarakat yang tinggi terhadap kedelai, sedangkan produktivitas kedelai di Indonesia yang rendah, mengharuskan Indonesia mengimpor kedelai dalam jumlah besar. Beberapa komoditi yang berpotensi menjadi pendamping kedelai, diantaranya koro pedang. Kandungan protein yang tinggi dan kemampuan tumbuh pada kondisi ternaungi menjadi segi positif dari koro pedang. Penelitian tentang tingkat naungan yang dapat ditolerir tanaman koro pedang didukung kombinasi pempukan yang baik, perlu dilakukan. Penelitian ini bertujuan untuk mempelajari karakteristik pertumbuhan dan pembungaan tanaman koro pedang pada kondisi ternaungai dan mendapatkan informasi mengenai pemupukan terbaik. Penelitian dilaksanakan di Desa Purwasari, Dramaga, Bogor pada bulan Mei hingga November 2016. Penelitian ini menggunakan rancangan petak terbagi dengan tiga ulangan. Naungan sebagai petak utama yang terdiri dari tanpa naungan, naungan $10 \%$ dan naungan $20 \%$. Kombinasi pemupukan sebagai anak petak terdiri dari urea $50 \mathrm{~kg} \mathrm{ha}^{-1}+\mathrm{SP}-36100 \mathrm{~kg} \mathrm{ha}^{-1}+\mathrm{KCl} 75 \mathrm{~kg} \mathrm{ha}^{-1}$, pupuk organik dan urea $25 \mathrm{~kg} \mathrm{ha}^{-1}+\mathrm{SP}-3650 \mathrm{~kg} \mathrm{ha}^{-1}+\mathrm{KCl} 37,5 \mathrm{~kg} \mathrm{ha}^{-1}+$ pupuk organik. Hasil penelitian menunjukkan bahwa naungan $10 \%$ menghasilkan tanaman dengan tinggi tanaman $18,35 \mathrm{~cm}$ dan $94,80 \mathrm{~cm}$, jumlah daun trifoliate 11,75 helai, jumlah cabang 2,47 cabang, jumlah infloresen per tanaman 21,54 infloresen dan jumlah kuncup bunga per infloresen 1 kuncup bunga. Pemupukan terbaik untuk tanaman koro pedang adalah $25 \mathrm{~kg} \mathrm{ha}^{-1}$ urea $+50 \mathrm{~kg} \mathrm{ha}^{-1} \mathrm{SP}-36+37,5 \mathrm{~kg} \mathrm{ha}^{-1} \mathrm{KCl}+$ pupuk organik.
\end{abstract}

Kata kunci : infloresen, karakteristik, $\mathrm{KCl}$, SP-36, urea 


\section{PENDAHULUAN}

Tanaman pangan di Indonesia sangat beragam, diantaranya padi, jagung dan kedelai. Kedelai merupakan salah satu komoditas pangan dengan kandungan karbohidrat sebesar 34,8 g dan protein sebesar 34,9 g (Suprapti, 2003). Salah satu produk olahan kedelai adalah tempe. Menurut Hermana (1985), bahwa tempe merupakan salah satu produk fermentasi kedelai yang disukai oleh masyarat Indonesia, karena harganya yang murah dan sumber proteinnya yang mencapai $18,3 \%$. Hal ini dibuktikan dengan peningkatan konsumsi tempe pada tahun 2014 sebesar 4,06\% (Pusdatin, 2014). Kebutuhan masyarakat yang tinggi terhadap kedelai, sedangkan produktivitas kedelai di Indonesia yang rendah, mengharuskan Indonesia

mengimpor kedelai dalam jumlah besar. Beberapa komoditi yang berpotensi menjadi pendamping kedelai, diantaranya koro pedang.

Koro pedang (Canavalia ensiformis) memiliki kandungan karbohidrat sebesar 45,2$5,6 \%$ dan protein $23,8-27,6 \%$, sehingga koro pedang dapat digunakan sebagai bahan baku produk protein rich flour (PRF) atau tepung kaya protein (Dewi, 2007). Koro pedang juga memiliki produktivitas lebih tinggi dibandingkan dengan kedelai. Produktivitas koro pedang merah (Canavalia gladiate) mencapai $720-1.500 \mathrm{~kg}$, berbeda dengan kedelai yang hanya berkisar antara 600-1.000 kg ha ${ }^{-1}$ (Ekayanake et al., 2007). Selain kandungan protein dan produktivitas yang tinggi, kemampuan tumbuh toleran pada kondisi ternaungi (Puslitbangtan, 2007) juga menjadi segi positif dari tanaman koro pedang.

Luas panen kedelai pada tahun 2010 hingga 2013 mengalami penurunan sebesar 3,33\% (BPS, 2015). Menurut Bappenas (2013), bahwa salah satu penyebab penurunan produksi kedelai dari tahun 2010 hingga 2013 adalah penurunan jumlah luas panen. Kemampuan koro pedang untuk tumbuh pada kondisi ternaungi dapat dimanfaatkan dengan sistem penanaman tumpang sari dengan tanaman perkebunan, sehingga tidak mengurangi jumlah luas panen kedelai.

Tanaman koro pedang akan tumbuh optimal bila mendapatkan sinar matahari penuh, namun pada kondisi ternaungi masih mampu menghasilkan biji dengan baik (Puslitbangtan, 2007). Salah satu upaya dalam mempertahankan pertumbuhan tanaman koro pedang yang optimal dengan pemberian pemupukan. Menurut Afifah (2014), dan Balitkabi (2014), bahwa koro pedang dapat tumbuh optimal memerlukan pemupukan adalah urea $50 \mathrm{~kg} \mathrm{ha}^{-1}$, SP-36 $100 \mathrm{~kg} \mathrm{ha}^{-1}$, dan KCl $75 \mathrm{~kg} \mathrm{ha}^{-1}$. Penelitian Nurbaetun (2016), hasil produksi kacang koro pedang yang ditanam dengan dosis pupuk urea 62,5 $\mathrm{kg} \mathrm{ha}^{-1}$; SP-36 $112,5 \mathrm{~kg} \mathrm{ha}^{-1} ; \mathrm{KCl} 87,5 \mathrm{~kg} \mathrm{ha}^{-1}$ dan jarak tanam $50 \mathrm{~cm} \times 50 \mathrm{~cm} \times 75 \mathrm{~cm}$ menghasilkan produksi terbaik pada kondisi lahan yang kurang subur dengan curah hujan yang tinggi, namun dosis pupuk NPK dan jarak tanam yang diperoleh tetap tidak berpengaruh terhadap produksi. Menurut Nelza (2016), bahwa meningkatnya dosis pemupukan yang diberikan berdampak negatif terhadap produksi polong dan biji.

Permasalahan koro pedang yang sering ditemui di lapangan, salah satunya adalah kuncup bunga dan bunga mekar yang gugur. Penelitian Nelza (2016), menunjukkan bahwa pemberian naungan mampu meningkatkan jumlah kuncup bunga yang terbentuk, namun persentase bunga mekar dan pembentukan polong tetap rendah. Menurut Puslitbangtan (2007), bahwa pertumbuhan tanaman koro pedang akan optimal bila mendapatkan sinar matahari penuh, namun pada kondisi ternaungi masih mampu menghasilkan biji

dengan baik.

Penelitian tentang persentase naungan yang dapat ditolerir tanaman koro pedang terhadap pemupukan yang baik, perlu dilakukan sehingga diharapkan dapat mengurangi jumlah kuncup dan bunga mekar yang gugur serta meningkatnya produksi koro pedang.

Tujuan penelitian ini adalah :

1. Mempelajari karakteristik pertumbuhan dan pembungaan tanaman koro pedang pada kondisi ternaungai tertentu.

2. Mendapatkan informasi mengenai kombinasi pemupukan terbaik terhadap pertumbuhan dan pembungaan tanaman koro pedang.

Hipotesis yang diajukan dalam penelitian ini adalah

1. Terdapat perbedaan karakteristik pertumbuhan dan pembungaan tanaman kacang koro pedang pada kondisi ternaungi tertentu.

2. Terdapat kombinasi pemupukan terbaik yang dapat digunakan dalam budidaya koro pedang

\section{METODE}

Penelitian dilakukan di Desa Purwasari, Kecamatan Dramaga, Cibereum, Bogor pada bulan April sampai dengan bulan November 2016. Bahan yang digunakan dalam penelitian ini adalah benih koro pedang yang dipanen pada Agustus 
2015 , paranet $10 \%$, paranet $20 \%$, pupuk urea, SP-36, KCl, pupuk kandang, bambu untuk rangka naungan, ajir untuk menompang tanaman, insektisida, bakterisida, fungisida dan pasir. Alat alat yang digunakan adalah lux meter untuk mengukur intensitas cahaya, timbangan, tali, meteran, alat pertanian, alat tulis dan kamera.

Rancangan yang digunakan adalah rancangan percobaan petak terbagi (Split Plot Design) dalam rancangan acak kelompok (RAK). Petak utama adalah tingkat naungan terdiri atas tanpa naungan, naungan 10\%, dan naungan $20 \%$ dan anak petak adalah kombinasi pemupukan terdiri atas urea $50 \mathrm{~kg} \mathrm{ha}^{-1}+\mathrm{SP}-36100 \mathrm{~kg} \mathrm{ha}^{-}$ ${ }^{1}+\mathrm{KCl} 75 \mathrm{~kg} \mathrm{ha}^{-1}$, pupuk organik dan urea $25 \mathrm{~kg}$ $\mathrm{ha}^{-1}+$ SP-36 $50 \mathrm{~kg} \mathrm{ha}^{-1}+\mathrm{KCl} 37,5 \mathrm{~kg} \mathrm{ha}^{-1}+$ pupuk organik.Terdapat 9 kombinasi perlakuan yang diulang sebanyak 3 ulangan, sehingga diperoleh 27 satuan percobaan. pengaruh perlakuan diuji menggunakan uji $\mathrm{F}$, apabila terdapat pengaruh nyata maka diuji lanjut dengan DMRT.

Persiapan lahan, diawali dengan membuang gulma yang ada di areal penanaman, selanjutnya dilakukan pengolahan tanah hingga tanah menjadi gembur. Petak satuan percobaan dibuat dengan ukuran $3,5 \mathrm{~m} \mathrm{x} \mathrm{4,5} \mathrm{m,}$ jarak antar petak $0,5 \mathrm{~m}$. Jarak tanam yang digunakan adalah $0,5 \mathrm{~m} \times 0,5 \mathrm{~m} \times 1 \mathrm{~m}$. Lubang tanam tiap petakan diberi pupuk kandang sebanyak 10 ton $\mathrm{ha}^{-1}$ dan diamkan selama dua minggu. Paranet dipasang saat waktu bera, sesuai dengan perlakuan dan diberi label pada setiap petak satuan percobaan. Benih koro pedang yang ditanam sebanyak 1 butir. Pemberian furadan dilakukan bersamaan dengan penanaman secara tugal. Pemupukan urea, SP-36, $\mathrm{KCl}$ dan pupuk organik dilakukan 1 minggu setelah tanam (MST) sesuai perlakuan yang ditentukan.

Penyulaman dilakukan apabila ada bibit yang tidak tumbuh diganti dengan benih baru. Penyiangan dilakukan intensif setiap minggunya secara manual, terutama pada fase vegetatif dan pembumbunan dilakukan agar perakaran tanaman kacang koro pedang kokoh dan tidak mudah rebah. Pemangkasan dilakukan pada buku ke-8 pada batang utama dan buku ke-4 pada cabang. Pengikatan cabang dilakukan agar cabang tidak mengikat tanaman sebelahnya. Pengendalian hama dilakukan dengan penyemprotan insektisida yang dilakukan intensif dengan disesuaikan tingkat serangan. Pengendalian penyakit dilakukan penyemprotan bakterisida dan fungisida. Pemberian mulsa dilakukan pada 10 MST, mulsa yang digunakan adalah jerami padi. Pemanen dilakukan pada saat polong berwarna coklat.
Pengamatan terdiri atas pengamatan deskriptif bunga, pengamatan kuantitatif pada fase vegetatif dan generatif. Pengamatan deskriptif bunga dilakukan pada 3 bunga terdiri atas panjang tangkai bunga, warna tangkai bunga, warna sepal, warna petal, jumlah stamen dan jumlah pistil. Pengamatan kuantitatif dilakukan pada 10 tanaman sampel pada setiap ulangan terdiri atas tinggi tanaman, jumlah daun trifoliate, jumlah cabang, luas daun, jumlah infloresen per tanaman, jumlah kuncup bunga per infloresen, jumlah bunga mekar per infloresen, jumlah polong per tanaman, panjang polong, jumlah biji per polong, bobot biji per polong, jumlah polong hampa per tanaman.

\section{HASIL DAN PEMBAHASAN}

\section{Kondisi Umum}

Berdasarkan data Balai Penelitian Agroklimat dan Hidrologi (Balitklimat), curah hujan selama bulan Mei hingga Oktober 2016 berkisar antara 293- $439 \mathrm{~mm}$, dengan suhu berkisar antara $26,0-27,1^{\circ} \mathrm{C}$ dan kelembaban udara berkisar antara $82-86 \%$. Curah hujan tersebut termasuk kriteria kelas curah hujan tinggi. Analisis curah hujan terbagi atas curah hujan rendah 0-100 $\mathrm{mm}$, curah hujan menengah 100-300 mm, curah hujan tinggi 300-500 mm dan curah hujan sangat tinggi. Hasil analisis tanah pada lahan penelitian pengaruh pemupukan menunjukkan bahwa kandungan C-organik dan $\mathrm{N}$-organik tergolong rendah dengan nilai berturut-turut $1,51 \%$, dan $0,17 \%$. Lahan penelitian memiliki ph netral yaitu 6,37.

Tanaman koro pedang dapat tumbuh sampai ketinggian tempat $2.000 \mathrm{~m}$ dpl, dan tumbuh baik pada suhu rata-rata $14{ }^{\circ} \mathrm{C}$ hingga 27 ${ }^{\circ} \mathrm{C}$ di lahan tadah hujan atau $12{ }^{\circ} \mathrm{C}$ hingga $32{ }^{\circ} \mathrm{C}$ di daerah tropik dataran rendah. Tanaman koro pedang putih dapat tumbuh baik pada curah hujan tinggi $4.200 \mathrm{~mm}$ pertahun dan curah hujan rendah sampai $700 \mathrm{~mm}$ pertahun. Tanaman koro pedang juga dapat tumbuh baik pada tanah asam sampai dengan kondisi netral $(4,4-6,8)$ dan juga pada daerah tergenang dan salin (Puslitbangtan,

2007). Jenis tanah pada lahan penelitian sesuai kriteria tumbuh koro pedang, namun curah hujan saat penelitian lebih tinggi dibandingkan deskripsi Puslitbangtan.

Awal penelitian tanaman koro pedang memberikan penampakan pertumbuhan yang baik. Daun dan cabang yang tumbuh dalam jumlah banyak, sehingga tanaman terlihat rimbun. Pemberian ajir dan pengikatan cabang dilakukan sehingga tanaman tidak mudah rebah. Curah 
hujan pada bulan Juni hingga Juli belum mempengaruhi pembungaan. Infloresen yang muncul lebih dulu, masih dapat membentuk bunga mekar.

Saat memasuki bulan Agustus hingga Oktober, curah hujan mengalami peningkatan, sehingga menyebabkan banyak bunga yang gugur dan polong yang membusuk. Menurut Kalie (2000), bahwa keguguran bunga dapat terjadi secara alami, nonpatogen, hama dan penyakit. Keguguran alami berasal dari bunga itu sendiri, sedangkan keguguran dari nonpatogen berasal dari iklim dan kesuburan lahan pertanaman. Ashari (2006), menyebutkan bahwa curah hujan yang tinggi berpengaruh terhadap proses pembungaan. Bunga menjadi busuk dan tidak mempunyai viabilitas lagi. Kepala putik yang busuk dan aktivitas serangga penyerbuk juga berkurang karena kelembaban yang tinggi tersebut. Hal tersebut menyebabkan pembuahan dan panen telah gagal. Penggunaan mulsa jerami dan pembungkusan polong dilakukan untuk menghindari polong menyentuh permukaan tanah dan busuk, namun hal tersebut tidak mengurangi busuk polong sehingga dilakukan pengikatan polong.

Penyakit dan hama yang menyerang tanaman koro pedang selama penelitian adalah penyakit layu bakteri (Pseudomonas sp.), virus mosaik (Soybean Mozaik Virus), busuk batang (Cendawan Phytium sp.), belalang (Valanga nigricornis), kumbang kedelai (Phaecionis inclusa), hama ulat polong (Ettiela zinchenella), dan ulat grayak (Spodoptera litura). Gulma yang ada selama penelitian adalah Eleusine indica, Axonopus compressu, Ageratum conyzoides, dan Borerria laeevi.

Pengamatan intensitas cahaya dilakukan pada pukul 08.00, 12.00, 14.00 dan 16.00. Peningkatan cahaya pada pukul 08.00 ke pukul 12.00 berkisar 11,3-76 klux. Pukul 12.00 ke pukul 14.00 pada bulan Agustus terjadi penurunan intensitas cahaya berkisar 27,3-46,7 klux. Peningkatan intensitas cahaya terjadi kembali pada pukul 14.00 ke pukul 16.00 berkisar 10,1-31 klux pada bulan September dan Oktober, namun pada bulan Agustus intensitas cahaya mengalami penurunan berkisar 36,82-48,53 klux.

\section{Deskripsi Bunga Tanaman Koro Pedang}

Tanaman kacang koro pedang memiliki panjang tangkai bunga sekitar $13-37 \mathrm{~cm}$. Tangkai bunga tanpa naungan memiliki warna hijau kemerahan, sedangkan tangkai bunga dengan perlakuan naungan memiliki warna hijau. Bunga koro pedang termasuk bunga lengkap yang terdiri atas stamen (alat kelamin jantan), pistil (alat kelamin betina), mahkota (korola), dan kelopak bunga (kaliks). Bunga koro pedang termasuk juga bunga majemuk, dalam satu kuncup terdapat 13 kuncup.

Bunga koro pedang memiliki 5 helai petal yang terdiri atas 1 helai yang berukuran paling besar disebut bendera (vexillum), 2 helai yang paling atas disebut lunas (carina) dan 2 helai yang ke samping disebut sayap (wings). Warna mahkota bunga kacang koro pedang adalah ungu keputihan dan warna kelopak adalah hijau. Bunga koro pedang memiliki 1 pistil berwarna putih dan 10 stamen yang berkelompok berwarna putih. Bunga muncul pada ketiak daun, batang utama dan cabang. Pemberian naungan menghasilkan warna tangkai bunga yang berbeda dengan perlakuan tanpa naungan.

\section{Pengaruh Naungan terhadap Karakter Tanaman Koro Pedang yang Diamati \\ Pemberian persentase naungan yang berbeda pada tanaman koro pedang menyebabkan perbedaan tinggi tanaman, jumlah daun trifoliate, jumlah cabang dan jumlah infloresen per tanaman. Pengaruh perlakuan naungan terhadap beberapa karakter yang diamati ditunjukkan pada $\quad$ Tabel}

Tabel 1. Komponen pengamatan dengan perlakuan naungan

\begin{tabular}{lcccc}
\hline \multirow{2}{*}{ Tolok Ukur } & \multirow{2}{*}{ Umur (MST) } & \multicolumn{3}{c}{ Persen Naungan } \\
\cline { 3 - 5 } & & $0 \%$ & $10 \%$ & $20 \%$ \\
\hline \multirow{2}{*}{ Tinggi tanaman $(\mathrm{cm})$} & 7 & $13,51 \mathrm{~b}$ & $18,35 \mathrm{a}$ & $18,28 \mathrm{a}$ \\
Jumlah daun trifoliate (helai) & 5 & $72,03 \mathrm{~b}$ & $94,80 \mathrm{a}$ & $83,96 \mathrm{a}$ \\
Jumlah cabang (cabang) & 3 & $14,49 \mathrm{a}$ & $11,75 \mathrm{~b}$ & $11,75 \mathrm{~b}$ \\
Jumlah infloresen per tanaman (infloresen) & 12 & $2,67 \mathrm{a}$ & $2,47 \mathrm{ab}$ & $2,36 \mathrm{~b}$ \\
\hline
\end{tabular}

Keterangan: angka-angka yang diikuti huruf yang sama pada baris yang sama menunjukkan tidak berbeda nyata pada uji lanjut DMRT taraf 5\%

Tanaman yang beri naungan $10 \%$ lebih tinggi dibandingkan petak naungan lainnya, namun tidak berbeda nyata dengan tinggi tanaman perlakuan $20 \%$ sebesar $99,6 \%$ dan $88,6 \%$ pada 3 dan 5 MST. Pertambahan tinggi tanaman sebesar $83,05 \mathrm{~cm}$. Pemberian naungan 
menyebabkan batang koro pedang mengalami pemanjangan ruas batang atau etiolasi hingga melilit tanaman sebelah. Hal ini karena intensitas cahaya matahari yang diterima tanaman menjadi rendah. Etiolasi pada batang merupakan mekanisme tanaman dalam mencari sinar matahari untuk bertahan dan beradaptasi dalam kondisi lingkungan yang suboptimum. Kondisi ternaungi membuat tanaman kedelai tumbuh lebih memanjang dibandingkan dengan pada keadaan terbuka. Tanaman kedelai pada jarak $140 \mathrm{~m}$ dari titik sumber cahaya cerobong pada keadaan ternaungi tampak semakin tinggi mencapai 192,4 cm dibandingkan dengan keadaan terbuka yang hanya mencapai 139,6 cm (Agusta dan Santosa, 2005).

Tanaman tanpa diberi naungan menghasilkan jumlah daun trifoliate lebih banyak dibandingkan petak naungan lainnya dan berbeda nyata terhadap perlakuan naungan $10 \%$ dan $20 \%$. Jumlah daun trifoliate pada tanaman tanpa naungan adalah 14,49 helai. Menurut Nelza (2016) bahwa jumlah daun tertinggi diperoleh pada perlakuan tanpa naungan yaitu 5,07 helai dan 12,2 helai berturut-turut pada umur 3 dan 5 MST.

Jumlah cabang pada tanaman tanpa naungan lebih banyak dibandingkan petak naungan lainnya. Tanaman tanpa naungan berbeda nyata dengan naungan $20 \%$, namun tidak berbeda nyata dengan tanaman yang diberi naungan $10 \%$. Jumlah cabang pada tanaman tanpa nuangan adalah 2,67 cabang, sedangkan tanaman yang diberi naungan $20 \%$ dan $10 \%$ adalah 2,36 dan 2,47 cabang. Penelitian Nelza (2016), menunjukkan semakin tinggi persentase naungan dapat menghambat jumlah cabang. Rata-rata jumlah cabang adalah 0,07-1,61 cabang pertanaman, 2,26-4,69 cabang pertanaman dan 5,33-7,52 cabang pertanaman pada umur 3,5 dan 10 MST.

Jumlah infloresen pada tanaman yang diberi naungan $10 \%$ lebih banyak dibandingkan petak ulangan lainnya. Tanaman yang beri naungan $10 \%$ berbeda nyata dengan perlakuan tanpa naungan dan naungan $20 \%$. Jumlah infloresen pada naungan $10 \%$ adalah 21,54 infloresen. Penelitian Nelza (2016), menunjukkan meningkatnya persentase naungan yang diberikan menyebabkan penurunan jumlah infloresen yang dihasilkan. Hal in diduga berkaitan dengan penurunan jumlah buku dan jumlah cabang yang merupakan tempat munculnya infloresen. Kondisi yang ternaungi akan meningkatkan pertumbuhan secara vertikal dan mengalami penghambatan munculnya cabang.

\section{Pengaruh Kombinasi Pupuk terhadap Jumlah Polong Hampa}

Perlakuan lain pada penelitian ini adalah kombinasi pupuk. Dosis dan jenis pupuk berbeda yang diberikan pada tanaman kacang koro pedang menyebabkan perbedaan jumlah polong hampa seperti yang ditunjukkan pada Tabel 2. Tanaman yang diberi pupuk dosis $25 \mathrm{~kg} \mathrm{ha}^{-1}$ urea $+50 \mathrm{~kg}$ $\mathrm{ha}^{-1} \mathrm{SP}-36+37,5 \mathrm{~kg} \mathrm{ha}^{-1} \mathrm{KCl}+$ pupuk organik menghasilkan jumlah polong hampa lebih sedikit dibandingkan pemupukan lainnya yaitu 0,20 polong.

Tabel 2. Pengaruh dosis pemupukan terhadap jumlah polong hampa

\begin{tabular}{lc}
\hline \multicolumn{1}{c}{ Perlakuan } & Jumlah Polong Hampa (polong) \\
\hline $50 \mathrm{~kg}$ ha-1 urea $+100 \mathrm{~kg}$ ha-1 SP-36 +75kg ha-1 KCl & $0,88 \mathrm{a}$ \\
pupuk organik ayam petelur & $0,91 \mathrm{a}$ \\
$25 \mathrm{~kg}$ ha-1 urea $+50 \mathrm{~kg}$ ha-1 SP-36 $+37.5 \mathrm{~kg}$ ha-1 $\mathrm{KCl}+$ pupuk & $0,20 \mathrm{~b}$ \\
\hline
\end{tabular}

Interaksi Naungan dan Kombinasi Pupuk terhadap Jumlah Kuncup Bunga Per Infloresen

Interaksi antara naungan dan kombinasi pupuk berpengaruh nyata terhadap jumlah kuncup bunga per infloresen pada 14 MST. Tanaman yang beri naungan $10 \%$ dan $25 \mathrm{~kg} \mathrm{ha}^{-1}$ urea +50 $\mathrm{kg} \mathrm{ha}{ }^{-1} \mathrm{SP}-36+37,5 \mathrm{~kg} \mathrm{ha}^{-1} \mathrm{KCl}+$ pupuk organik lebih tinggi jumlah kuncup per infloresen dibandingkan dengan interaksi petak tanaman naungan dan kombinasi pupuk lainnya. Interaksi tersebut menghasilkan jumlah kuncup per infloresen sebanyak 1,00 kuncup (Tabel 3).
Menurut Nelza (2016), bahwa tanaman yang tumbuh pada kondisi ternaungi akan memiliki jumlah kuncup bunga yang lebih banyak dibandingkan dengan tanpa naungan. Kondisi lingkungan bercekaman, tanaman akan meningkatkan jumlah organ generatif dalam rangka meningkatkan peluang untuk bereproduksi dan memperbanyak keturunan secara cepat. Penelitian Alfiah (2014), bahwa jumlah kuncup bunga yang terbentuk pada perlakuan $23 \mathrm{~N} \mathrm{~kg} \mathrm{ha}^{-}$ ${ }^{1}+36 \mathrm{SP}-36 \mathrm{~kg} \mathrm{ha}^{-1}+45 \mathrm{~K}_{2} \mathrm{O} \mathrm{kg} \mathrm{ha}{ }^{-1}$ adalah yang terbanyak pada saat 8 dan 9 MST. 
Tabel 3. Pengaruh pemupukan terhadap jumlah kuncup bunga per infloresen

\begin{tabular}{|c|c|c|c|}
\hline \multirow{2}{*}{ Jumlah kuncup bunga per infloresen } & \multicolumn{3}{|c|}{ Persen Naungan } \\
\hline & $0 \%$ & $10 \%$ & $20 \%$ \\
\hline $50 \mathrm{~kg}$ ha-1 urea $+100 \mathrm{~kg}$ ha- $1 \mathrm{SP}-36+75 \mathrm{~kg}$ ha- $1 \mathrm{KCl}$ & $0,00 \mathrm{~b}$ & $0,27 \mathrm{~b}$ & $0,45 b$ \\
\hline pupuk organik ayam petelur & $0,00 \mathrm{~b}$ & $0,20 \mathrm{~b}$ & $0,00 \mathrm{~b}$ \\
\hline $\begin{array}{l}25 \mathrm{~kg} \text { ha- } 1 \text { urea }+50 \mathrm{~kg} \text { ha- } 1 \mathrm{SP}-36+37.5 \mathrm{~kg} \text { ha- } 1 \mathrm{KCl}+\text { pupuk } \\
\text { organik }\end{array}$ & $0,00 \mathrm{~b}$ & $1,00 \mathrm{a}$ & $0,00 \mathrm{~b}$ \\
\hline
\end{tabular}

\section{KESIMPULAN}

Naungan $10 \%$ menghasilkan tanaman dengan tinggi tanaman $18,35 \mathrm{~cm}$ dan $94,80 \mathrm{~cm}$, jumlah daun trifoliate 11,75 helai, jumlah cabang 2,47 cabang, jumlah infloresen per tanaman 21,54 infloresen dan jumlah kuncup bunga per infloresen 1 kuncup bunga. Pemupukan terbaik untuk tanaman koro pedang adalah $25 \mathrm{~kg} \mathrm{ha}^{-1}$ urea $+50 \mathrm{~kg} \mathrm{ha}^{-1} \mathrm{SP}-36+37,5 \mathrm{~kg} \mathrm{ha}^{-1} \mathrm{KCl}+$ pupuk organik.

\section{DAFTAR PUSTAKA}

Agusta, H., I. Santosa. 2005. Indeterminasi sekuensial pembungaan dan ketidakmampuan produksi kedelai di lapang akibat penambahan cahaya kontinu pada kondisi terbuka dan ternaungi. Bul.Agron (33) (3) 24-32.

Alfiah, N.A.2014. Pengaruh dosis pupuk NPK dan aplikasi rhizobium terhadap produktivitas dan mutu benih koro pedang (Canavalia ensiformis). Skripsi. Institut Pertanian Bogor. Bogor.

[Balitkabi] Balai Penelitian Tanaman KacangKacangan dan Umbi. Kelayakan dan teknologi budidaya kacang koro pedang (Canavalia ensiformis L.) Skripsi. Fakultas Pertanian Hasil Pertanian. Universitas Jember. Jember.

[Bappernas] Badan Pembangunan dan Perencanaan Nasional. 2013. Rencana Pembangunan Jangka Menegah Nasional Bidang Pangan dan Pertanian 2015-2019. [Internet] [diunduh 2017 Mei 02] tersediada pada http://bappenas.go.id
[BPS] Badan Pusat Statistika. 2015. Luas panen kedelai di Provinsi (ha). [Internet] [diunduh 2017 Mei 03] tersediada pada http://bps.go.id

Ekanayake, S., K. Skog, N-G. Asp. 2007. Canavanine Content In Sword Beans (Canavalia gladiata): Analysis and Effect of Processing. Journal Food and Chemical Toxicology Vol. 45: 797-803.

Havlin, J.L., J.D. Beaton, S.L. Tisdale, W.L. Nelson. 1999. Soil Fertility and Ferilizers, An Introduction to Nutrient Management. 6th Edition. Prentice Hall. New Jersy. 499 p. Hermana. 1985. Pengolahan kedelai menjadi berbagai bahan makanan. Bogor :Pusat Penelitian dan Pengembangan Tanaman Pangan.

Nelza, A. 2016. Studi fenologi, karakter hasil dan mutu benih tanaman kacang koro pedang (Canavalia ensiformis L.) pada perbedaan kondisi naungan dan pemupukan. Tesis. Institut Pertanian Bogor. Bogor.

Nelza, A., T.K. Suharsi, M. Surahman. 2016. Perkembangan Karakter Generatif Kacang Koro Pedang (Canavalia ensiformis L.) pada Perbedaan Kondisi Naungan dan Pemupukan. Hal 164.Prosiding Seminar Nasional dan Kongres Perhimpunan Agronomi Indonesia 2016. Bogor.

[Pusdatin] Pusat Data dan Informasi. 2014. Buletin konsumsi pangan vol 5 no 2 . [Internet] [diunduh 2017 April 11] tersediada pada http://pusdatin.setjen.go.id.

Suprapti, L. 2003. Pembuatan Tempe. Yogyakarta. Kanisius. 